\title{
ACCESSIBLE TOURISM AS THE FACTOR IN CREATING THE IMAGE OF SERBIAN WINERIES AS A SEGMENT OF AGRITOURISM SUPPLY
}

\author{
Jelena Jević ${ }^{1}$, Slobodan Čerović2 ${ }^{2}$ Goran Jević3 ${ }^{3}$ Miroslav Čavlin ${ }^{4}$ \\ *Corresponding author E-mail: jelenajevic1984@gmail.com
}

A R T I C L E I N F O
Review Article
Received: 12 November 2019
Accepted: 09 December 2019
doi:10.5937/ekoPolj1904157J
UDC 338.48:[663.285:338.48-53:63

Keywords:

Accessible tourism, Wine tourism, Rural tourism, Agritourism, Accessibility of wineries to accessible tourism consumers

JEL: Q19, L6, M14, Z32

\begin{abstract}
A B S T R A C T
Accessible tourism denotes tourism offering equity and full participation to all categories of customers in tourism. The aim of the paper is to examine the attitudes of owners and managers of wineries in order to determine the influence of dependable variable related to "attitude to special needs citizens" on image and reputation of wineries which is measured through the following independent variables: district where a winery is located, the size of a winery and membership in a cluster. With this aim in mind in 2017 a survey was conducted on a sample of 81 wineries. One of the conclusions of the analysis shows the influence of a membership in a cluster or association on the attitude of wineries` owners and managers towards the importance of accessibility of wineries to accessible tourism consumers as an elements of the supply that is relevant for the image and reputation of a winery.
\end{abstract}

(C) 2019 EA. All rights reserved.

\section{Introduction}

Alarge number of separate studies pointed to the issues of demand, offer and organization of travel for people with disabilities. In time, numerous research works have been focused on identifying more precisely the leisure activities of these customers, i.e.

1 Jelena Jević, M.A., Assistant, College of Tourism, Bulevar Zorana Djindjica no.152a, Belgrade, Serbia, phone number+ 381112698 222, e-mail: jelenajevic1984@gmail.com, ORCID ID (https://orcid.org/0000-0002-2100-791X)

2 Slobodan Čerović, Ph.D., Full Professor, Singidunum Universtity, Danijelova no. 32, Belgrade, Serbia, phone number + 381113093275 e-mail: scerovic@singidunum.ac.rs, ORCID ID (https://orcid.org/0000-0002-4646-2476)

3 Goran Jević, Ph.D., Assistant, College of Tourism, Bulevar Zorana Djindjica no.152a, Belgrade, Serbia, phone number + 381112698 222, e-mail: jevicgoran82@gmail.com, ORCID ID (https://orcid.org/0000-0002-3007-6714)

4 Miroslav Čavlin, Ph.D., Associate Professor, University Business Academy Novi Sad Faculty of Economics and Engineering Management, Cvećarska Street no. 2, 21000 Novi Sad, Serbia, phone number +381 63581 714, e-mail: cmiros@gmail.com ORCID ID (https://orcid.org/0000-0001-7465-7441)

http://ea.bg.ac.rs 
correlation between people with disabilities and tourism. Gradually, it was established that the main issue of their exclusion from tourism was due to various physical barriers and then from the society as a whole towards this customer category. This research was mostly related to the attitude of employees in tourism segments such as hospitality and transportation, while a small number of authors paid attention to the possibilities of accessible tourism development in rural areas characterized by wine production. From the standpoint of wine tourism, availability of wineries to accessible tourism consumers may bring not only economic benefits but also positive impact on the image and reputation of a winery in its geographical and business environment.

\section{Accessible tourism}

For the quality market research of accessible tourism, it is necessary to define the segments included in this market, i.e. its target market. UNWTO Compilation represents a retrospective of recommendations for the period of 1975-2015 and it considers accessible tourism as tourism aimed at visually impaired, hearing impaired, mobility impaired, cognitively impaired as well as those with temporary disability in addition to families with young children and people over 65 years old, iso-called third age (UNWTO, 2016: 107). It is noticeable that barriers are not related only to the persons with disabilities but to all customers who at some stage in their lives require accessible facilities, which points to the necessity for further research and definition of the correlation between tourism and accessibility, especially in the context of the need assessment of its users.

As the concept of accessible tourism was developed as non-discriminatory and inclusive, there have been different forms but not a general definition accepted by all. Judging by the attention and scope it gathers, this concept is still to be developed and defined. European Network for Accessible Tourism (ENAT, 2012) states that 'universal tourism', 'inclusive tourism', 'accessible tourism' is tourism accessible to everyone, with or without disabilities, including people who have difficulties with mobility, vision, hearing, cognitive or intellectual and psycho-social disability, seniors and people with temporary disability. In the references, the most quoted definition is by authors Darcy and Dickson, (2009: 34), and in 2013 it was accepted and confirmed by the UNWTO in the publication Recommendations on Accessible Tourism (UNWTO, 2013:4) according to which 'Accessible tourism allows people with access requirements, including mobility, visual, hearing and cognitive dimension of access, to function with equity and dignity through the delivery of universally designed tourism products, services and environments. This definition includes all people, including those travelling with children in prams, people with disabilities and seniors'. As stated in the ENAT report (Vos et al., 2007: 16), "All tourists, with or without disabilities, should have a choice of selecting accommodation, destinations and attractions they want to visit because of the location, atmosphere and price, and not only because it is the only accessible option adapted to their requirements, that is the key to accessible tourism". 
Regarding the potential size of this market, it is estimated that over 750 million of people over the world and between 37 and 45 million of people in Europe have some disability (Buhalis et al., 2005). According to the OSSATE project, even 130 million of people in Europe have accessibility requirements, including seniors, which points to the strong connection between older age and disabilities, around $70 \%$ of this group have physical and financial means to travel. Economic aspect of this statement was approved by various international studies, e.g. 54.3\% persons with disabilities travel in Germany. However, $37 \%$ gave up the idea of travelling since they could not find the appropriate offer and $48 \%$ would travel more often if there were accessible offers (Neumann et al., 2004). Although a large proportion of Europeans would support improvement of accessible tourism offers, a small number of tour operators is aware of this potential and a small number understands their needs and expectations (Praća et al., 2017). In addition to the size of the accessible market alone including the mentioned categories of customers, the added economic value to justify the investment in adapting first of all accommodation capacities lies in the fact that certain categories of these customers are not able to travel alone and they need to bring along someone they can trust, either a caregiver, member of the family, often a driver also, thus at least one person more and sometimes more than one will come with them (Mićović, 2019). The attention given to accessible tourism over the world is marked by the World Tourism Day in 2016 themed as 'Tourism for All - Promoting Universal Accessibility' by compiling examples of good practice in the accessible service chain, which confirms its global importance (UNWTO: 2016).

Without doubt, accessible tourism has brought numerous changes to accommodation sector that require efforts by the management and all available resources in order to maximize the use of accessible accommodation capacities to full occupancy. Accessibility required by this market is important in the aspect of the size of the market, i.e. its demand, as well as of their expenditure. Accessible tourism offers and experiences are still very limited, first and foremost, by obstacles such as physical barriers, limited transportation, accommodation and attraction options that are not adapted, then followed by information barriers, lack of information, inadequate and/or incomplete information or unadapted or badly designed web pages.

\section{Wine tourism as an element of agritourism}

Wine tourism includes independent or organized visits to vineyards, wineries, wine festivals, wine demonstrations with the purpose of wine tasting and gaining experience through a visit to a wine region (Kunc, 2009; Alant and Bruwer, 2004; Alant and Bruwer, 2010; Hall and Macionis, 1998; Lopez-Guzman, 2011; Koch et al., 2013; Hall et al., 2000b; Dodd, 2000). Grimstad (2011) views wine tourism as a combination of aesthetically pleasant landscape and wine consumption, while Razović (2015) states that the most important elements of wine tourism are: hospitality, winery staff expertise on wine, wine festivals, atractive scenery, affordable accomodation, availability of information, gastronomic specialties, traditional wine villages and the like. A number 
of authors regard wine tourism as strongly connected with rural tourism (Mitchell et al., 2012; Marques, 2006; Schererr et al., 2009; Quadri, 2012; Razović, 2015), others see it as a type of special interest tourism (Bruwer, 2003) while Lopez-Guzman (2011) perceives a strong link between wine and gastronomic tourism. Yuan et al. (2005) state that wine tourism is represented in literature as a form of rural tourism, agritourism, cultural tourism, industrial tourism and special interest tourism. Thus, Jovanović et al. (2015) regard wine tourism as a means of development of agritourism and observe that numerous private wineries are located in rural areas. The authors state that wine tourists have the opportunity to try hands-on activities ranging from grape picking to wine making. A more precise position of wine tourism is defined by Robinson and Novelli (2005) who specify the existence of five niches, where wine tourism is a micro niche of rural tourism. Also, Bruwer (2003) agrees that wine tourism is a part of special interest tourism and its rural component, and emphasizes that this form of tourism is gaining importance in tourism economy of countries in the world. Rabotic (2013: 158) observes that it is ,virtually impossible to draw a line between wine and rural tourism because vineyards, as well as most wineries, are situated in rural areas, so wine tourism is often regarded as a segment of rural tourism". Štetić (2007) views wine tourism as a part of rural tourism, stating that Timoc wineries are an important highlight of rural tourism in Eastern Serbia. The same opinion is shared by Mesarić-Žabćić and Breslauer (2010), emphasizing the importance of wine tourism for rural tourism of Medjumurska County, as well as by Jovanović (2013) who regards wineries of Gudurice village near Vrsac as a part of rural tourism of South banat region. In accordance with this statement is the research conducted by Tuck and Gartner (2014) in New England (USA) where the results show that $70 \%$ of wineries is located in rural areas.

Northwud (2000:14) claims that wine tourism as one aspect of rural and agritourism has become very popular in many countries with suitable growing conditions. According the same author wine tourism is a unique and specialised form of agri-tourism that is just beginning to be recognized as a profitable industry which generally causes little damage to the environment. The same author states that there are many links between wineries and rural tourism in Niagara region: not only does rural tourism depend on the wineries, but many of the wineries also depend on tourism in order to be sustained in the future. Tourism helps wine imdustry in many ways and brings a wide range of advantages for wineries and the region where wineries are located. Simultaniously, wine industry contributes to tourism and economy of Niagara region.

Certain authors explain the difference between agritourism, village and rural tourism, explaining that the term agritourism denotes all tourist and recreational activities related to agricultural activities (Hall et al., 2017; Hall and Jenkis, 1998), while village tourism denotes a complex activity that takes place away from urban areas, specifically in the countryside (Hall et al., 2017). Along the same lines Bramwell and Lane (1994) explain village tourism as multi-faceted activity which includes a country holiday as well as eco activities such as trekking, riding, adventure, education and the like. These authors view rural tourism as holidaymaking in rural areas. Popesku (2008) perceives 
the difference between these two terms, stating that in many countries agritourism is considered as a type of village tourism, which can be perceived as a part of a wider term named rural tourism (Tasić, 2018). The same author states that agritourism takes place in agricultural areas where services are provided by agricultural producers, while the term rural tourism denotes village households, rural lifestyle and holidaymaking in rural areas. Similar attitude is shared by Lane (1994) who sees rural tourism as connected with tourist activities in the rural environment. On the other hand, Brčić-Stipčević et al. (2010) draw a line between rural and agritourism in the way the difference is stated by Croatian Chamber of Economy, where rural tourism denotes tourist activities in rural areas, while agritourism stands for economic linking of agricultural and tourism activities (Jovanović et al., 2017).

According to the above mentioned attitudes of a number of authors we can conclude that wine tourism is closely related to rural tourism. Namely, wine tourism supply imply rural areas because vineyards and wine cellars, being the basic elements of wine tourism, are typically situated in rural areas. However, if tourist activities of wine tourists include work in the vineyard (hoeing, pruning...) or participation in wine production, then we can perceive it as agritourism within rural tourism.

In our country wine tourism mainly takes place in rural areas where most of the wineries included in wine tourism are located and this type of tourism in Serbia is presented in the form of wine routs, just as it is the case in the majority of European countries.

According to the division adopted by Tourism Organization of Serbia, wine routes in Serbia are named after wine regions and these are: Pocersko-Valjevski wine route, wine route Negotin County (Negotinska krajina), Knjazevac wine route, Mlava wine route, Toplica wine route, Nis wine route, Leskovac wine route, Vranje wine route, wine route Three Morava Rivers, Belgrade wine route, Sumadija wine route, Srem wine route, Subotica wine route, wine route Telecka, Tisa region wine route, Banat wine route, South Banat wine route, South Metohija wine route (TOS, 2017: 2).

\section{Wine tourism as an element of agritourism supply along with examples of tours adapted for accessible tourism consumers}

There is a number of examples of wine tours adapted for accessible tourism consumers. American association "Wine road" founded in California in 1976, encompasses wine route supply in the Alexander, Dry Creek, and Russian River valleys of Northern Sonoma County. From its modest beginning as an organization of 9 wineries, it has grown into an association of nearly 200 wineries and 50 lodgings and hosts numerous programmes, events and services designed to enhance the experience of the visitors to this region. On their website (WINEROAD, 2019) while browsing through wineries and wine routes, it is possible to choose a winery or wine route according to its name, region, type of wine, while it is also possible to search by amenity so that wine tours adapted to accessible tourism consumers can be easily found. There are 83 wineries adapted to accessible tourism consumers where they can buy and taste wine as well as savour the gastronomic 
specialties of the region in a pleasant setting and travel through picturesque countryside. The level of attention to accessible tourism users can be seen in the fact that the website of the association, as well as the websites of each of the wineries, offer the option of accesibility menu where the entire websites' content is available to users with various forms of disabilities. For users of this type of tourism obtaining correct and unambiguous information is of utmost importance as it gives the sense of safety (WINEROAD, 2019)

One of the leading European websites which promotes services adapted to accessible tourism consumers (Disabled accessible travel, 2019) promotes wine tours in European countries famous for wine as a part of European city tours. Thus, among others, Italian wine routes and wineries are recommended (Disabled accessible travel, 2019). In this tour, beautiful wines can be tasted and visitors can experience firsthand the love for wines the family has. Depending on starting point, the timing of this accessible wine tour in Italy can vary accordingly. This visit offers an introduction to the family who makes the wines and of course their exquisite wines. On this guided tour, knowledge about the history of the family is shared through a short-movie and you can see how the wine is produced. Besides this, the winery's innovative architecture can be enjoyed. The tour includes wine tasting of three estate-grown wines. Visitors can see the vineyards, the cellar where the wine ages, and the beautiful architecture of the building. So not only taste buds have a joy-ride here, but eyes also have a wonderful time. The winery looks out over the beautiful Tuscany landscape, so it is definitely a must-visit. When it comes to touring Spanish wine regions and wineries, it is possible to go on a wine tour in the vicinity of one of the most famous and most visited tourist hubs, the city of Barcelona. After a 30-minute scenic drive enjoying the landscape, visitors arrive at the eye-catching vineyards. The family has experience in hosting disabled visitors so everything will go smoothly. (Disabled accessible travel, 2019). Online tour operator (Rome and Italy, 2019). who deals mostly with promotiong tourism products of Rome as well as the whole Italy has a special segment on their website adapted to accessible tourism users, where along with tourist attractions of a region, wine tours and visits to wineries are also promoted as one of the most important tourism potentials of the country (Rome and Italy, 2019). Accessible tourism users can tour the wineries in the company of a licenced tour guide, taste famous wines along with bruschetta, olives and prosciutto, and enjoy a scenic drive through the region. Excursions throughout Italy are also promoted on a website of the association Fausta Accessible Transportation (Accessible transportation in Rome, 2019) that specializes in transfer of accessible tourism consumers, offering comfort and safety of travel, vehicles adapted to all categories of accessible tourism and professional staff. One of the specialized tours is named "Tuscany, Gastronomic and Cultural Tour, Wine Tasting" (Accessible transportation in Rome, 2019). On this tour visitors can explore and learn the history of "Chianti" by seeing the hills and vineyards that have made this particular wine one of the biggest names across the world. These hills will create an amazing backdrop for a tasting of this wine. Tour starts at "Castello Banfi", a stunning 13th century village located near Montalcino, which is now an independent vineyard. There are numerous castle wine cellars where people can experience different stages of wine production from the vineyard all the way through to the bottling but most importantly the different steps in the process of 
creation of "Chianti" and "Brunello di Montalcino". In the "Glass Museum" it is possible to see and admire some extremely old and rare wine bottles and wine glasses with some examples coming from the Venetian glass area. In the "Balsameria" visitors can explore the secrets of ancient traditional seasoning which have been passed down for centuries within the castle known as the Etruscan balsamic vinegar which is obtained from the aging of the grape juice which makes this product a perfect addition to most dishes. The tour ends in Siena, where visitors can explore the amazing sights of the town. Some of the sights that visitors will explore will be the "Duomo", "Palazzo Comunale" in the "Piazza del Campo". With its unique structure in a shell shape the Piazza is the home to one of the oldest horse racing activities called the "Palio" that has been hosted at the Piazza for centuries. The Palio happens twice a year during summer season.

On behalf of the German federal government, German National Tourist Board plays an important role in the promotion of Germany as a travel destination on the international market. One of the tours is called „On a journey along the Wine Route. An accessible pilgrimage for all!“ (GERMANYTRAVEL, 2019). This trail from Koblenz to Konstanz boasts ever-changing scenery and exciting cultural history. The entire route is accessible, so it is perfect for hikers and accessible tourism users who like to hike with Riesling from the vineyards of the Romantic Middle Rhine Valley, which is hugely popular due to its mild Mediterranean climate. With top wines and plenty of holiday spirit sitting by Lake Constance, in Konstanz, where Wine Route ends, locals love to tell visitors the story of how the first ever Pinot Noir grapes were grown in the nearby village of Bodman by Charlemagne's great-grandson. This pilgrimage route takes hikers past ancient castles, churches, monasteries and chapels. It offers many opportunities to meditate, including historic sites and pleasant places to stop.

An example of a Serbian winery which focuses on accessible tourism users is Temet winery. Wishing to contribute to the concept of inclusion, and to offer accessible tourism users the pleasure of wine tasting and winery touring, Temet winery had ramps and accessible toilets constructed on their grounds. Moreover the wine labels are written in Braille Alphabet, which is a unique approach in this type of tourism in Serbia (TEMET, 2019).

\section{Research Methodology}

Surveys were sent to 140 wineries listed in the official catalogue of Tourism Organization of Serbia, and 65 answers were collected. In order to obtain more answers, and to receive even more precise information about attitudes to marketing activities, an additional survey was given to owners and managers of wineries that are not included in the official catalogue. Additional surveys were conducted during special wine events such as wine fairs, by face-to-face interview, subsequent email correspondence or phone conversation. Thus another 16 responses were obtained, which totalled 81 respondents. The research was conducted from 23 March 2017 to 28 September 2017. 


\section{Data processing}

Starting from descriptive statistics measures we used arithmetic mean with standard deviation. Frequencies and percentages were used to show qualitative variables. The differences between groups were defined through one-factor analysis of variance (ANOVA). We also used Student $t$ test for large independent samples. For the purposes of prediction, we used univariante linear regression. Statistical relevance was defined at the level of probability of zero hypothesis from $p \leq 0.05$. Statistical analysis was conducted in the SPSS version 24 (Statistical Package for the Social Sciences) for Windows.

\section{Sample Characteristics}

According to the region (Table 1), our sample mostly included Srem region (30,9\%), Three Morava Rivers region (18,5\%) and South Banat region (8,6\%). The division of regions has been adopted from the official division of wine regions of Serbia. The regions are represented in this percentage because wineries are located mostly in these three regions.

According to the size of a winery (Table 1), in our sample, the largest percentage of $43,2 \%$ belonged to small wineries (5-30.000 litres), while middle range wineries (30100.000 1) made up $33,3 \%$ of our research sample. In this sample, the majority of the wineries do not belong to a wine or tourism cluster, while $40,5 \%$ of the wineries are members of an association. Most of the wineries are members of the Association of wine-makers of Sumadija, while 14,3\% belong to Fruska Gora cluster of grape producers and winemakers "Alma Mons", another 10,7\% belong to the Association of grape producers and winemakers "Srem-Fruška gora", while 10,7\% belong to the Association of wine-makers of Zupa "Knights" wine".

Table 1 What is the importance of the attitude to accessible tourism consumers for the image and reputation of a winery

\begin{tabular}{|l|r|}
\hline & \multicolumn{1}{|r|}{$\mathbf{N = 8 1}$} \\
\hline Region of the winery, n (\%) & $15(18,5 \%)$ \\
\hline Three Morava Rivers & $7(8,6 \%)$ \\
\hline South Banat region & $25(30,9 \%)$ \\
\hline Srem region & $6(7,4 \%)$ \\
\hline Šmadija region & $6(7,4 \%)$ \\
\hline Belgrade region & $22(27,2 \%)$ \\
\hline Other wine regions* & $2(2,5 \%)$ \\
\hline Size of winery, n (\%) & $8(9,9 \%)$ \\
\hline Limited production (up to 1000 litres) & $35(43,2 \%)$ \\
\hline Very small (from 1000 to 5000 litres) & \\
\hline Small (from 5.000 to 30.000 litres) & \\
\hline
\end{tabular}




\begin{tabular}{|l|r|}
\hline & \multicolumn{1}{|c|}{$\mathbf{N = 8 1}$} \\
\hline Region of the winery, $\mathrm{n}(\%)$ & $27(33,3 \%)$ \\
\hline Middle- range (from 30 to 100.000 litres) & $9(11,1 \%)$ \\
\hline Large (over 100.000 litres) & $32(40,5 \%)$ \\
\hline Membership in a cluster of association $n(\%)$ & $47(59,5 \%)$ \\
\hline Yes & $3,24 \pm 1,27(1-5)$ \\
\hline No & $\begin{array}{l}\text { What is the importance of the attitude to accessible tourism consumers for } \\
\text { the image and reputation of a winery, } M \pm S D \text { (Min - Max) }\end{array}$ \\
\hline
\end{tabular}

*Other wine regions encompass regions with less than $5 \%$ in the sample: Negotinska krajna $(\mathrm{N}=4)$, Mlava region $(\mathrm{N}=2)$, Nis region $(\mathrm{N}=3)$, Subotica region $(\mathrm{N}=4)$, Toplica region $(\mathrm{N}=1)$,

Vranje region $(\mathrm{N}=2)$, Knjazevac region $(\mathrm{N}=1)$, Backa region $(\mathrm{N}=2)$, Pocersko Valjevski

Region $(\mathrm{N}=1)$, Potiski region $(\mathrm{N}=1)$ and Region Telecka $(\mathrm{N}=1)$.

Source: Author's calculation

The importance of the attitude to accessible tourism consumers for the image and reputation of a winery was assessed on 5-point scale of Likert type. Average importance equals $3,24 \pm 1,27$ which represents middle- range evaluation of this characteristic of a winery.

\section{Research results}

The research investigated if there was a statistical difference in the way wineries in different regions assess the importance of attitude to accessible tourism users for the image of winery (Table 2). ANOVA test shows that there is no important statistical difference $(p>0,05)$. All regions consider this aspect mildly important (mid-range on the scale): Three Morava Rivers Region (3,53 $\pm 1,59)$, South Banat region $(3,29 \pm 0,75)$, Srem region $(3,25 \pm 1,39)$, Sumadija region $(3,83 \pm 1,32)$, Belgrade region $(2,20 \pm 0,44)$ and Other wine regions $(3,10 \pm 1,04)$.

There are no significant differences that arise from the size of the winery. Namely, notwithstanding the size of the winery, the owners and managers similarly assess the importance of the attitude towards accessible tourism consumers for the image of the winery $(\mathrm{p}>0,05)$.

There is a statistically important difference in the perception of the importance of the attitude towards accessible tourism consumers for the image of the winery in relation to the membership in a cluster $(p<0,01)$. Namely, the wineries that belong to a cluster or association give more importance to the influence of the attitude towards accessible tourism consumers on the image of the winery $(3,73 \pm 1,36)$, compared to the wineries that are not members of a cluster or association $(2,89 \pm 1,10)$. 
Table 2 The importance of the attitude to accessible tourism consumers related to the region and size of a winery as well as its membership in a cluster

\begin{tabular}{|c|c|c|}
\hline & $\mathbf{N}=\mathbf{8 1}$ & $\mathbf{p}$ \\
\hline \multicolumn{2}{|l|}{ Region of winery, $\mathrm{n}(\%)$} & \multirow{7}{*}{$0,338^{\mathrm{a}}$} \\
\hline Three Morava Rivers & $3,53 \pm 1,59$ & \\
\hline South Banat region & $3,29 \pm 0,75$ & \\
\hline Srem region & $3,25 \pm 1,39$ & \\
\hline Sumadija region & $3,83 \pm 1,32$ & \\
\hline Belgrade regon & $2,20 \pm 0,44$ & \\
\hline Other wine regions & $3,10 \pm 1,04$ & \\
\hline \multicolumn{2}{|l|}{ Size of winery, $\mathrm{n}(\%)$} & \multirow{6}{*}{$0,560^{\mathrm{a}}$} \\
\hline Limited production (up to 1000 liters) & $3,00 \pm 2,82$ & \\
\hline Very small (from 1000 to 5000 liters) & $2,71 \pm 0,95$ & \\
\hline Small (from 5.000 to 30.000 liters) & $3,21 \pm 1,25$ & \\
\hline Middle- range (from 30 to 100.000 liters) & $3,54 \pm 1,27$ & \\
\hline Large (over 100.000 liters) & $3,00 \pm 1,32$ & \\
\hline \multicolumn{2}{|l|}{ Membership in a cluster of association $n(\%)$} & \multirow{3}{*}{$<0,01^{\mathrm{b}}$} \\
\hline Yes & $3,73 \pm 1,36$ & \\
\hline No & $2,89 \pm 1,10$ & \\
\hline
\end{tabular}

${ }^{\mathrm{a}} \mathrm{ANOVA}$ test; ${ }^{\mathrm{b}}$ Student's $\mathrm{t}$ - test; $\mathrm{p}$ - statistical significance;

Note: mean \pm standard deviation are showen in table

Source: Author's calculation

Pivac (2012:147) holds a view that for wine networking it is important to create a connection between grape producers, wine producers, hoteliers, restaurants, employees in tourism sector as well as representatives of local authorities and researchers in the field of tourism.

By using univariante linear regression we researched the influence of membership in a cluster or association on the perception of importance of the attitude to accessible tourism consumers for the image and reputation of a winery (Table 3 ). The percentage of explained variance amounts to $9,4 \%$, while the influence is statistically important $(\operatorname{Beta}=0,326(0,276-1,408), \mathrm{p}<0,05)$. Membership in a cluster was coded as binary variable ( $1=$ there is membership in a cluster, $0=$ there is no membership in a cluster). Thus, the influence of belonging to a cluster was confirmed in terms of perception of the importance of the attitude to accessible tourism consumers. The wineries that are members of a cluster give more importance to this aspect. 
Table 3 The influence of membership in a cluster on perception of importance of the attitude towards accessible tourism consumers

\begin{tabular}{|l|c|c|c|c|}
\hline \multirow{2}{*}{ Dependent variables } & \multirow{2}{*}{$\begin{array}{c}\text { Independent } \\
\text { variables }\end{array}$} & \multicolumn{3}{|c|}{$\begin{array}{c}\text { Univariante linear regression } \\
\text { analysis }\end{array}$} \\
\cline { 3 - 5 } & & Beta (95\% CI) & p & $\begin{array}{c}\text { Adjusted R } \\
\text { Square }\end{array}$ \\
\hline $\begin{array}{l}\text { What is the importance of } \\
\text { the attitude to accessible } \\
\text { tourism consumers for the } \\
\text { image and reputation of a } \\
\text { winery? }\end{array}$ & $\begin{array}{c}\text { Membership in a } \\
\text { cluster or association }\end{array}$ & $0,326(0,276-1,408)$ & $<0,05$ & 0,094 \\
\hline
\end{tabular}

p - statistical significance

Source: Author's calculation

Authors of the paper hold the view that this result confirms the importance of wine clusters and associations for the development of wine tourism and implementation of world trends. Namely, owners and managers of Serbian wineries that are a part of wine or tourism clusters are included in education and training and are aware of the importance of accessibility for the image and reputation of the winery (their attitude is however usually limited to visitors with disabilities, notably wheelchair users). Adaptation of the supply to the accessible tourism consumers may serve as an additional basis for marketing activities and presentation of the company as socially responsible. Nowadays attention of consumers is paid to the image a company has in the society, and the way the company treats different target groups, so that adaptation to the accessibility tourism consumers and informing the society about it enables better positioning and influencing consumers through this aspect of socially responsible behaviour. By accepting this concept of doing business and informing the society about it through different sorts of communication, a winery can diversify itself from the competition which may enable better positioning on the market, greater loyalty of buyers because of the positive perception of the winery, and consequently better sales of products and services.

\section{Conclusions}

Creating and managing desired image and reputation represents a basis for successful positioning of a winery in the consciousness of visitors, no matter if they have already been wine tourists or it is their first encounter with the type of tourism. Examples from various countries in the world show that accessible tourism consumers start to visit wineries more frequently, which means that owners and managers of wineries are aware of the advantages of the diversification of the supply. Based on this research conducted among owners and managers of wineries about the importance of the attitude to accessible tourism consumers for the image and reputation of a winery the results showed that looking at the variable of region, the greatest importance to this is given in Sumadija region $(3,83 \pm 1,32)$, while the least importance was perceived in wineries 
of Belgrade region $(2,20 \pm 0,44)$. As to the size of the winery, the research showed that midle-range wineries (wineries that produce from 30.000 to 100.000 litres of wine per year) consider accessibility most important $(3,54 \pm 1,27)$. The least importance of accessibility is perceived in small wineries which produce from 5.000 to 30.000 litres of wine per year. Owners or managers of wineries that belong to a cluster or association showed higher level of awareness of the importance of accessibility $(3,73 \pm 1,36)$ compared to wineries that are not members of a cluster or association $(2,89 \pm 1,10)$.

Univariant regression model proved the influence of the membership in a cluster on the perception

\section{Conflict of interests}

The authors declare no conflict of interest.

\section{References}

1. Alant, K., Bruwer, J. (2004). Wine tourism behaviour in the context of a motivational framework for wine regions and cellar doors. Journal of Wine Research, 15:27-37.

2. Alant, K. Bruwer, J. (2010). Winery visitation sets. Intra-regional spatial movements of wine tourists in branded regions. International Journal of Wine Business Research, 22 (2): 191-210.

3. Accessible transportation in Rome, Specializes transfer in Rome for accessible tourism consumers, Retreived October 25, 2019, from https://accessibletransportationrome.com/

4. Accessible wine routes in Germany, Retrieved October 25, 2019, from https:// www.germany.travel/en/leisure-and-recreation/spiritual-travel/pilgrimages/thewine-route.html

5. Brčić-Stipčević, V., Petjak, K., Renko, S., (2010). Ekoagroturizam - pokretač održivog razvoja turizma, Zagreb: Ekonomski fakultet Zagreb.[in English: BrčićStipćević, V., Petjak, K., Renko, S., (2010). Eco-tourism - initiator for sustainable tourism development. Zagreb: Faculty of Economics and Business. Zagreb].

6. Bruwer, J. (2003). South African wine routes: Some perspectives on the wine tourism industry's structural dimensions and wine tourism product. Tourism Management, 24 (4): 423-435.

7. Buhalis, D., Eichhorn, V., Michopoulou, E., Miller, G., (2005). Accessible Market and Stakeholder Analysis, One-Stop-Shop for Accessible Tourism in Europe (OSSATE), University of Surrey, UK

8. Darcy, S. and Dickson, T. (2009). "A whole-of-life approach to tourism: the case for accessible tourism experiences". Journal of Hospitality and Tourism Management, Vol. 16 No. 1, pp. 10-11.

9. Disabled accessible travel, Accessible wine tour in Italy, Retreived October 23, 2019, from https://disabledaccessibletravel.com/accessible-destinations/italy/ accessible-wine-tour-in-italy/ 
10. Disabled accessible travel, Accessible wine tasting near Barcelona, Retreived October 23, 2019, from https://disabledaccessibletravel.com/accessibledestinations/spain/accessible-barcelona/accessible-wine-tasting-near-barcelonaapprox-4-hours/

11. Dodd, T. H., (2000). Influences on cellar door sales and determinants of wine tourism success: results from Texas wineries. In: Hall, M., Shapers, L., Cambourne B., and Macionis, N. (Ured.). Wine tourism around the world-Development, management and markets (136-149). England: Butterworth Heinemann

12. European Network for Accessible tourism (ENAT). (2012)., Takayama declaration, Retrieved October 17, 2019, from https:/www.accessibletourism.org/resources/ takayama_declaration_top-e-fin_171209.pdf

13. Getz, D., Brown, G. (2006). Benchmarking wine tourism development: The case of the Okanagan Valley, British Columbia, Canada. International Journal of Wine Marketing, 18 (2): 78-97.

14. Grimstad, S. (2011). Developing a framework for examining business-driven sustainability initiatives with relevance to wine tourism clusters. International Journal of Wine Business Research, 23 (1): 62-82.

15. Hall, C. M., Johnson, G., Cambourne, B., Macionis, N., Mitchell, R., Sharples, L. (2000b). Wine tourism: an introduction. U: Hall, M., Shapers, L., Cambourne B., and Macionis, N. (Ured.). Wine tourism around the world-Development, management and markets. (1-24). England: Butterworth Heinemann

16. Hall, C.M., Macionis, N. (1998). Wine tourism in Australia and New Zealand. U: Butler, R.W., Hall, C.M., Jenkins, J.M.(Ured.). Tourism and Recreation in Rural Areas. (267-298). John Wiley \& Sons.

17. Jovanović, D., Muhi, B., Anđelković, A. (2015). Vinarije i putevi vina kao sredstvo za razvoj agroturizma u Srbiji. Turističko poslovanje, 15: 87-93.[in English: Jovanović, D., Muhi, B., Anđelković, A. (2015). Winaries and wine routes as a tool for the development of agritourism in Serbia. Tourism Business, 15, 87-93.].

18. Jovanović, D., Milenković, N., Damnjanović, R. (2017). Ocenjivanje i predviđanje potreba potrošača. Oditor-časopis za Menadžment, finansije i pravo, 3(1): 3751. 70-79. [in English: Jovanović, D., Milenković, N., Damnjanović, R. (2017). Assessing and anticipating consumer needs. Oditor-Journal of Management, Finance and Law, 3 (1): 37-51. 70-79.].

19. Jovanović, V. (2013). Tematski turizam. Beograd: Univerzitet Singidunum, [in English: Jovanović, V., (2013). Thematic tourism. Belgrade. Singidunum University].

20. Koch J., Martin, A. and Nash, R. (2013). Overview of perceptions of German wine tourism from the winery perspective. International Journal of Wine Business Research, 25 (1): 50-74.

21. Kunc, M. H. (2009). Forecasting the development of wine tourism: a case study in Chile. International Journal of Wine Business Research, 21 (4): 325-338

22. Lane, B., (1994). What is rural tourism? Journal of Sustainable Tourism, 2 (1-2):7-21. 
23. Lopez-Guzman, T., Rodriguez-Garcia, J., Sanchez-Canizares, S. and Lujan-Garcia, M. J. (2011). The development of wine tourism in Spain. International Journal of Wine Business Research, 23 (4): 374-386.

24. Marques, H. (2006). Research report: Searching for complementarities between agriculture and tourism - the demarcated wine-producing regions of northern Portugal. Tourism Economics, 12 (1): 147-155.

25. Mesarić-Žabćić R.and Breslauer, V. (2010). Međimurska vinska cesta kao generator razvoja županije. Hrvatski znanstveno stručni skup o menadžmentu u turizmu i sportu, Međumursko Veleučilište u Čakovcu, 1 (1): 244-257. [in English: MesarićŽabćić R.and Breslauer, V. (2010). Međimurje Wine Road as a Generator of County Development. Croatian Scientific Conference on Management in Tourism and Sport, Polytechnic of Međumurje in Čakovec, 1 (1): 244-257.].

26. Mićović, S. and Miletić, J. (2019). Poslovni subjekt kao osnova održivosti razvoja, Održivi razvoj, 1(1): 43-51.[in English: Mićović, S. and Miletić, J. (2019). Business as a base for Sustainable Development, Sustainable Development, 1 (1): 43-51.].

27. Mitchell, R., Charters, S., Albrecht, J. N. (2012). Cultural systems and the wine tourism product. Annals of Tourism Research, 39 (1): 311-335.

28. Neumann, P., Reuber, P. (2004). Economic Impulses of Accessible Tourism for All (Vol. 526). Berlin: Study commissioned by the Federal Ministry of Economics and Technology \& Federal Ministry of Economic and Labour (BMWA)

29. Northwoo, G.M. (2000). "The role of wine tourism in economic development: A case study of Niagara Region (Ontario)". Thesis and Dissertations (Comprehensive). 421.

30. Pivac, T. (2012). Vinski turizam Vojvodine. Novi Sad: Prirodno-matematički fakultet Univerziteta u Novom Sadu-Departman za geografiju, turizam i hotelijerstvo. [in English: Pivac, T. (2012). Wine tourism of Vojvodina. Novi Sad: Faculty of Science, University of Novi Sad - Department of Geography, Tourism and Hotel Management].

31. Popesku, J. (ed.) (2008). Menadžment turističke destinacije. Beograd, Univerzitet Singidunum.[in English: Popesku, J. (ed.) (2008). Management of the tourist destination. Belgrade, Singidunum University.].

32. Praća, N., Paspalj, M. and Paspalj, D. (2017). Impact of modern agriculture to sustainable development of guidelines. Oditor-časopis za Menadžment, finansije $i$ pravo, 3(1): 37-51.

33. Quadri, D. L. (2012). An experience economy analysis of tourism development along the Chautauqua-Lake Erie Wine Trail. Doktorski rad, USA: Iowa State University

34. Rabotić, B. (2013). Selektivni oblici turizma. Beograd: Visoka turistička škola [in English: Rabotić, B. (2013). Selective forms of tourism. Belgrade: College of Tourism].

35. Razović, M. (2015). Vinski turizam kao posebni oblik turističke ponude Dalmacije. Zbornik radova Veleučilišta u Šibeniku, (3)4:51-67. [in English: Razović, M. (2015). Wine tourism as a special form of tourist offer in Dalmatia. Proceedings of the Polytechnic of Šibenik, (3) 4: 51-67]. 
36. Robinson, M., Novelli, N. (2005). Niche tourism: an introduction. U: Novelli, M. (Ured.). Niche Tourism-contemporary issues, trends and cases. (1-14), Oxford: Elsevier.

37. Rome and Italy, Accessible services, Retrieved October 23, 2019, from https:// www.romeanditaly.com/accessible/

38. Scherrer, P., Alonso, A., Sheridan, L. (2009). Expanding the Destination Image: Wine Tourism in the Canary Islands. International Journal of Tourism Research, 11: 451-463.

39. Štetić, S. (2007). Posebni oblici turizma. Beograd: izdavač je autor [in English: Stetić, S. (2007). Special forms of tourism. Belgrade: Author is the publisher].

40. Temet winery, about the winery, Retrieved October 24, 2019, from http://www.temet. $\underline{\text { rs/temet vinarija.php }}$

41. Tourism Organization of Serbia (TOS). (2017). Serbian wine roads, Retrieved October 19, 2019, from http://www.srbija.travel/upload/documents/brosure/2017/ putevivina2017.pdf

42. Tasić, J. (2018). Budući trendovi i pravci razvoja ruralnog turizma u Srbiji i u svetu. Oditor - časopis za Menadžment, finansije i pravo, 4(3), 7-19. [in English: Tasic, J. (2018). Future trends and directions of rural tourism development in Serbia and worldwide. Oditor - Journal of Management, Finance and Law, 4 (3), 7-19.].

43. Tuck, B., Gartner, W. (2014). Vineyards and Wineries in the New England States, a status and economic contribution report. Minesota: University of Minnesota Extension

44. Vos S., Ambrose I., (2007). Services and Facilities for Accessible Tourism in Europe, working together to make tourism in Europe accessible for all, ENAT, Retrieved October 25, 2019, from http://www.accessibletourism.org/resources/enat study-2 services and facilities en.pdf

45. Yuan, J. J., Cai, L. A., Morrison, A. M., Linton, S. (2005). An analysis of wine festival attendees' motivations: a synergy of wine, travel and special events? Journal of Vacation Marketing, 11(1):41-58.

46. Wine road, Sonoma Country, CA, Winery search, Retrieved November 01,2019, from https:/www.wineroad.com/wineries/page/3/?winery name\&region\&wine type\&amenity $=$ Handicap $\% 20$ Accessible

47. World Tourism Organization (UNWTO). (2013). Recommendations on Accessible Tourism, Retrieved October 19, 2019, from http:/cf.cdn.unwto.org/sites/all/files/ docpdf/recommendationsaccesstourismforallenok.pdf

48. World Tourism Organization (UNWTO). (2016). Compilation of UNWTO Recommendations 1975-2015, Retrieved October 15, 2019, from https:/www.eunwto.org/doi/book/10.18111/9789284417797

49. World Tourism Organization (UNWTO). (2016). World Tourism Day, Retrieved October 16, 2019, from http://cf.cdn.unwto.org/sites/all/files/pdf/wtd_message_ unwtosg_2016_en.pdf 
